\title{
Determination of Quality of Life of Patients Undergoing Lower Extremity Amputation Due to Peripheral Angiopathy (Diabetic Foot)
}

\author{
(1) Zeki Taşdemir
}

Department of Orthopedics and Traumatology, University of Health

Sciences, Kartal Dr. Lütfi Kırdar Training and Research Hospital, İstanbul, Turkey

Submitted: 13.01.2020 Accepted: 27.01 .2020

Correspondence: Zeki Taşdemir SBÜ Kartal Dr. Lütfi Kırdar Eğitim ve Araştırma Hastanesi, Ortopedi ve Travmatoloji Kliniği, İstanbul, Turkey E-mail: drtazeki@gmail.com

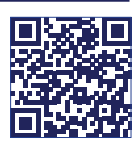

Keywords: Phantom pain; prosthesis satisfaction survey; stump pain; TAPES. Attribution-NonCommercial 4.0 International License.

\begin{abstract}
Objective: Amputations lead to major changes in one's life in terms of daily life and functionality. Limitations in body structures and bodily functions due to amputation affect the level of activity and social participation of the individual. In this study, the Turkish version of the Trinity Amputation and Experience Scale (TAPES) questionnaire was aimed to investigate the relationship between the quality of life and functional level of re-participation after normal amputation.
\end{abstract}

Methods: A total of 48 patients who were admitted to the Orthopedics and Traumatology Clinic of our tertiary care hospital, regardless of age and sex, underwent lower extremity amputation due to diabetic foot were included in the study. Trinity Amputation and Experience Scale (TAPES) questionnaires of all patients were recorded and filled out.

Results: Of the 48 patients included in the questionnaire, $36(75.0 \%)$ were male and 12 (25.0\%) were female. A total of eight (16.7\%) patients were amputated above the knee level and $40(83.3 \%)$ patients under the knee. There were $14(29.2 \%)$ patients who used the prosthesis for more than 12 hours a day, and 34 (70.8\%) patients who used the prosthesis for less. The mean age of the patients was $54.4 \pm 19.4$ years (range: II-86 years). The total satisfaction score rate was $63.1 \pm 20.5 \%$ (range: $20-92 \%$ ).

Conclusion: Our study is one of the rare studies in Turkey about the satisfaction of prosthesis and some other compliance criteria in amputated patients. Our study data showed that especially stump and phantom pain were significantly related to both daily utilization of the prosthesis, compliance scores, and satisfaction scores for the prosthesis, and these pains affect the psychological state of the amputees.

\section{INTRODUCTION}

Limb amputation is a life-changing surgery. ${ }^{[1]}$ Peripheral vascular diseases, especially diabetes mellitus, are the most common causes of amputation indication. ${ }^{[1-3]}$

Amputations lead to major changes in one's life in terms of daily life and functionality. ${ }^{[2]}$ Limitations in body structures and body functions due to amputation affect the level of activity and social participation of the individual. [3] Participation limitations in amputees are particularly related to obstacles in the physical/structural environment for lower extremity amputees. ${ }^{[4]}$ Lower extremity amputation is a surgical method that creates irreversible effects on function in daily life. ${ }^{[1]}$ Although amputation is seen as a failure of treatment in the community, rehabilitation-focused health care workers regard this as a reconstruction in cases where the extremity cannot be rescued. ${ }^{[5]}$ Amputees have the potential to adapt to social and daily activities by providing mobility with prostheses. ${ }^{[6]}$

The level of satisfaction obtained from an artificial limb after amputation, which creates great physical, psychological, and social problems on a person's life, is directly related to the quality of life related to health. ${ }^{[2,7-9]}$ Considering that the prosthesis is a tool to replace the natural limb of the user, it will be more clearly understood how important the satisfaction of the prosthesis is. ${ }^{[3,8,9]}$

As far as we can reach, there are few studies examining the levels of reparticipation in normal life and the factors related to reparticipation in normal life of individuals who have undergone amputation surgery in our country. In this study, the Turkish version of the Trinity Amputation and Experience Scale (TAPES) questionnaire was aimed to investigate the relationship between the quality of life and functional level of reparticipation after normal amputation. 


\section{MATERIALS AND METHODS}

This study was approved by the local ethics committee and planned prospectively.

\section{Patients and tests}

Forty-eight patients admitted to the Orthopedics and Traumatology Clinic of our tertiary care hospital regardless of age and sex and underwent lower extremity amputation due to diabetic foot were included in the study. All patients' TAPES ${ }^{[8]}$ questionnaires were recorded.

In general, TAPES questionnaire was used to evaluate the satisfaction of prosthetic volunteers. The questionnaire included psychosocial adjustment, compliance with constraints, prosthesis satisfaction, health and capacity, and stump and phantom pain scoring. Scoring of negative questions was recorded in reverse order. Stump and phantom pain scores were scored according to the pain level. The maximum score in the survey is $100 \%$ and the minimum score is 0 , which means $0 \%$ satisfaction. This score was obtained by multiplying the maximum score of the total score of the subjects by 100 points.

Inclusion criteria were unilateral lower extremity amputation, post-operative and pre-operative prosthesis training, prosthesis training, and prosthesis training for at least 6 months and 18 years of age.

Patients who did not have the capacity to walk before the lower extremity problem and did not belong to the lower extremity after the operation and who lost their walking potential (paraplegia, development of Alzheimer, neurological diseases, etc.) were excluded from the study.

\section{Statistical analysis}

All statistical analyses were performed using SPSS 25.0 software (IBM SPSS, Chicago, IL, USA). Descriptive data were given as numbers and percentages. The comparisons between the groups in terms of categorical variables were made by Chi-square test and Fisher's exact test. Kolmogorov-Smirnov test was used to confirm whether continuous variables were suitable for normal distribution. Differences between groups in terms of continuous variables Student's t-test and mean values between multiple groups were compared by analysis of variance. Results were evaluated in $95 \%$ confidence interval and $p<0.05$ was considered statistically significant. Bonferroni correction was performed where necessary.

\section{RESULTS}

Of the 48 patients included in the questionnaire, 36 $(75.0 \%)$ were male and $12(25.0 \%)$ were female. A total of $8(16.7 \%)$ patients were amputated above the knee level and $40(83.3 \%)$ patients were below the knee. There were I $4(29.2 \%)$ patients who used the prosthesis for more than $12 \mathrm{~h}$ a day, and $34(70.8 \%)$ patients who used the prosthesis for less time (Table I). The mean age of the pa-
Table I. Distribution of some variables of the patients with amputation

\begin{tabular}{lcc}
\hline Variable & $\mathbf{n}$ & $\%$ \\
\hline $\begin{array}{l}\text { Gender } \\
\text { Male }\end{array}$ & 36 & 75.0 \\
$\quad$ Female & 12 & 25.0 \\
Amputation level & & \\
$\quad$ Above knee & 8 & 16.7 \\
$\quad$ Below knee & 40 & 83.3 \\
Daily life of the prosthesis & & \\
$\quad<12$ h & 34 & 70.8 \\
$\geq 12 \mathrm{~h}$ & 14 & 29.2 \\
\hline
\end{tabular}

tients was $54.4 \pm 19.4$ years (range: I I-86 years). The mean completion time of the questionnaires was $8.4 \pm 1.3$ (range: 6-II) $\mathrm{min}$. The mean daily use time of the prosthesis was I I.8 \pm 5.7 (range: 2-24) h (Table 2).

The average satisfaction score for the aesthetics of the prosthesis was $81.7 \pm 26.6 \%$ (range: $25-100 \%$ ), the overall satisfaction score rate for the prosthesis was $60.8 \pm 24.4 \%$ (range: $20-100 \%$ ), and the total satisfaction score rate for the prosthesis was $63.1 \pm 20.5 \%$ (range: $20-92 \%$ ) (Table 2). The rate of patients who stated that they were satisfied with the aesthetics of the prosthesis, that is, "unsatisfied" or "very satisfied" in the questionnaire, was $45.9 \%$.

The average psychosocial general adjustment score rate was $65.0 \pm 26.4 \%$ (range: $20-100$ ), the social adjustment score rate was $63.2 \pm 18.9 \%$ (range: $32-92 \%$ ), and the rate of compliance with social constraints was $51.2 \pm 22.3 \%$ (range: 20-92), athletic restraint tolerance score $61.1 \pm 31.1 \%$ (range: $8.3-100 \%$ ), one-step climbing stairs, walking around $\mathrm{I} \mathrm{km}$ satisfaction rate of daily activities such as $59.0 \pm 22.7 \%$ (range: $33-100$ ), and the rate of limitation tolerance score in social activities was $70.1 \pm 26.4 \%$ (range: 33.3-100) (Table 2). The mean health status score was $65.0 \pm 26.4 \%$ (range: $20-100 \%$ ) and the physical capacity score rate was $65.0 \pm 26.4 \%$ (range: $20-100 \%$ ) (Table 2).

The mean stump pain compliance score was $65.0 \pm 26.4 \%$ (range: $20-100 \%$ ) and the phantom pain compliance score rate was $65.0 \pm 26.4 \%$ (range: $20-100 \%$ ) (Table 2 ). The mean stump $(p=0.013)$ and phantom pain scores $(p<0.00 I)$ were significantly higher in females than in males (Table 3).

No significant difference was found between amputated above the knee and amputated below the knee in terms of general adjustment, social cohesion, compliance against constraints, prosthesis satisfaction, and stump and phantom pain scores ( $p>0.05$ for each) (Table 3).

The mean psychosocial adjustment $(p=0.02)$, social adjustment $(p=0.025)$, compliance with social activities $(p=0.014)$, satisfaction with the aesthetics of the prosthesis $(p<0.00 \mathrm{I})$, and general satisfaction with the prosthesis $(p=0.014)$ scores were significantly lower than those who used daily $12 \mathrm{~h}$ or more. Mean stump $(\mathrm{p}<0.00 \mathrm{I})$ and phan- 
Table 2. Mean values of questionnaire scores in patients with amputation

\begin{tabular}{|c|c|c|c|c|}
\hline Variables & Mean & SD & Minimum & Maximum \\
\hline Age & 54.4 & 19.4 & $\mathrm{II}$ & 86 \\
\hline Daily prosthesis usage time & 11.8 & 5.7 & 2 & 24 \\
\hline Survey completion time & 8.4 & 1.3 & 6 & 11 \\
\hline \multicolumn{5}{|l|}{ Psychosocial adjustment } \\
\hline Psychosocial general adjustment & 65.0 & 26.4 & 20.0 & 100 \\
\hline Social adjustment & 63.2 & 18.9 & 32.0 & 92.0 \\
\hline Compliance with social restrictions & 51.2 & 22.3 & 20.0 & 92.0 \\
\hline \multicolumn{5}{|l|}{ Functional constraint compliance } \\
\hline Compliance with athletic restriction & 61.1 & 31.1 & 8.3 & 100 \\
\hline Compliance with restrictions in daily activities & 59.0 & 22.7 & 33.3 & 100 \\
\hline Compliance with restriction in social activities & 70.1 & 26.4 & 33.3 & 100 \\
\hline \multicolumn{5}{|l|}{ Prosthetic satisfaction } \\
\hline The aesthetics of the prosthesis & 81.7 & 26.6 & 25.0 & 105.0 \\
\hline The use of the prosthesis & 60.8 & 24.4 & 20.0 & 100 \\
\hline Overall satisfaction with the prosthesis & 63.1 & 20.5 & 20.0 & 92.0 \\
\hline \multicolumn{5}{|l|}{ Pain adjustment } \\
\hline Stump pain compliance & 26.9 & 27.4 & 0 & 100 \\
\hline Phantom pain compliance & 31.7 & 28.2 & 0 & 90.0 \\
\hline \multicolumn{5}{|l|}{ Health and capacity } \\
\hline Health status & 66.7 & 23.1 & 20.0 & 100 \\
\hline Physical capacity & 66.7 & 25.9 & 20.0 & 100 \\
\hline
\end{tabular}

Table 3. Relationship between mean scores according to amputation level and daily prosthesis use

\begin{tabular}{lccc}
\hline Score & Gender & Amputation level & Daily prosthesis usage time \\
\hline Psychosocial general adjustment & 0.803 & 0.161 & 0.02 \\
Social cohesion & 0.114 & 0.052 & 0.025 \\
Compliance with social constraints & 0.023 & 0.159 & 0.191 \\
Compliance with athletic restrictions & 0.288 & 0.785 & 0.956 \\
Compliance with restrictions in daily activities & 0.004 & 0.454 & 0.687 \\
Compliance with restrictions in social activities & 0.145 & 0.423 & 0.014 \\
Satisfaction with the aesthetics of the prosthesis & 0.386 & 0.534 & $<0.001$ \\
Satisfaction with the use of the prosthesis & 0.266 & 0.464 & 0.384 \\
General satisfaction of the prosthesis & 0.266 & 0.448 & 0.014 \\
Stump pain & 0.013 & 0.920 & $<0.001$ \\
Phantom pain & $<0.001$ & 0.239 & 0.046 \\
\hline
\end{tabular}

tom pain scores $(p=0.046)$ were significantly higher in this group compared to the other group (Table 3).

Stump pain scores: psychosocial adjustment $(p=0.028$; $r=-0.317)$, compliance with social restrictions $(p=0.044$; $r=-0.292$ ), satisfaction with prosthetic aesthetics $(p=0.014 ; r=-0.338)$, satisfaction with prosthesis use $(p=0.014 ; r=0.293)$ and overall satisfaction with the prosthesis $(p=0.014 ; r=-0.35)$. The phantom pain score was also adjusted to social $(p=0.014 ; r=-0.42)$, athletic $(p=0.014 ; r=-0.462)$, and daily activities $(p=0.014$; $r=-0.312)$ and to the satisfaction of the aesthetics of the prosthesis $(p=0.014) ; r=-0.287)$, satisfaction with the use of the prosthesis $(p=0.014 ; r=-0.314)$, and overall satis- faction with the prosthesis $(p=0.014 ; r=-0.336)$. Stump and phantom pain scores were also significantly correlated with each other $(p<0.000 ; r=-0.502)$

\section{DISCUSSION}

It is of great importance that the individual can return to normal life and improve the quality of life after amputation. The patient's satisfaction with the prosthesis and the determination of the new functional level of the patient affects the ability to improve the quality of life. Life expectancy of each patient after amputation may also affect satisfaction level of prosthesis. ${ }^{[10-12]}$ 
Therefore, attempts to determine the satisfaction of amputee patients with prosthesis are important..$^{[7,10-13]}$ There are some questionnaires developed in this direction. TAPES prosthesis satisfaction questionnaire was used in our study. The Prosthesis Satisfaction Questionnaire was developed by Gallagher and MacLachlan ${ }^{[8]}$ and it was reported that repeated measurements yielded clinically highly reliable results. For the Ist time in our country, TAPES survey was conducted by Topuz et al. ${ }^{[9]}$ It was stated that it was reliable and valid. It was emphasized that TAPES questionnaire is a versatile tool that can be used by academicians and physiotherapists in psychosocial adjustment, activity restriction, satisfaction with prosthesis, phantom and stump pain, and various medical problems in amputee patients. ${ }^{[9]}$

The satisfaction of the prosthesis is related to the usefulness of the prosthesis, the functional status of the person, the social burden, reactions from the family and the close environment, ${ }^{[14]}$ comfort and aesthetics aspects of the prosthesis, ${ }^{[15,16]}$ and pain. ${ }^{[17,18]}$ It has been reported that satisfaction with prosthesis may vary with personal factors such as amputation level, age, and gender. ${ }^{[19,20]}$

Şimşek et al. ${ }^{[12]}$ found that the average prosthesis satisfaction rate was $77.3 \%$. Sinha et al. ${ }^{[2]]}$ reported the average functional satisfaction rate as $85.6 \%$ in their TAPES questionnaire. Kark and Simmons ${ }^{[14]}$ reported this rate as $80.1 \%$. Engin et al. ${ }^{[22]}$ reported that $83 \%$ of their patients were satisfied with the prosthesis in general. In our study, the average overall prosthesis satisfaction rate was $63.1 \%$. The reason that the rates in the literature are quiet satisfactory may be due to the fact that patients see prosthesis as a new chance to improve their quality of life after amputation. However, according to the literature, we attribute our low satisfaction rate to the fact that phantom pain management is not performed adequately and to increased level of patients' expectations.

Van de Weg and Van der Windt ${ }^{[23]}$ found that their patients' satisfaction rate of climbing stairs was $50.3 \%$. They also reported that their patients' satisfaction with prosthesis was $61.1 \%$. In our study, the rate of satisfaction with prosthesis was $61.1 \%$ in terms of athletic restriction, such as running, sports activities, or climbing several floors, and was $59.0 \%$ in terms of daily activities such as climbing a single floor and walking around $\mathrm{I} \mathrm{km}$. Our satisfaction rate in athletic activities was higher than expected.

In our study, the prosthesis satisfaction rate was found to be $70.1 \%$ in terms of restriction on social activities. It should be aimed to increase these rates and to allow patients to walk more easily with their prostheses.

Sinha et al. ${ }^{[2]}$ found that the average overall compliance rate of the patients in terms of psychosocial adjustment was $84.6 \%$. In their study, they found that the average social adaptation rate was $71.7 \%$ and the compliance rate against social constraints was $51.3 \%$. In our study, the average overall psychosocial adjustment rate was $65.0 \%$, the social adjustment rate was $65.2 \%$, and the compliance rate was
$51.2 \%$. The fact that our general and social adjustment rates are low indicates that patients still have problems in limb loss, prosthesis, and getting used to the environment. However, they seem to have better adaptation to personal skills.

When the survey sections were examined one by one, it was found that the highest average score $(81.7 \%)$ was satisfied with the aesthetic features of the prosthesis such as shape and appearance. The lowest mean scores were stump pain (26.9\%) and phantom pain (31.7\%).

In our study, no significant difference was found between amputated above the knee and amputated below the knee in terms of general adjustment, social cohesion, compliance against constraints, prosthesis satisfaction, and stump and phantom pain scores. Despite the small number of patients amputated above the knee level, this finding reveals that there is no significant difference between those who lost a large part of their legs and those who lost a small part, contrary to the expectations in terms of artificial limb habituation, acceptance of artificial limb, not disturbing the view of society, and problems in terms of work. This proportional similarity is remarkable, although the patient who lost a large part of his leg had to adjust to this traumatic stress and the larger artificial limb.

Murray ${ }^{[24]}$ found that the absence of pain and longer daily use of prosthesis were significantly associated with functional satisfaction from the prosthesis. Similarly, Sinha et al. ${ }^{[2]]}$ reported that there was a relationship between longer daily use of prosthesis without phantom pain and prosthesis satisfaction. In our study, the average psychosocial general adjustment and social adjustment scores and satisfaction scores for the prosthesis were found to be significantly lower in patients who used the prosthesis less than $12 \mathrm{~h}$ daily. In the short-term group, the mean score of stump and phantom pain was significantly higher than the long-term group. These data indicate that the high level of pain in patients reduces the duration of daily use of the prosthesis. Patients with more stump and/or phantom pain cannot use the prosthesis for a long time. Improved pain management in such patients may prolong prosthesis use. There may be a belief that the use of prosthesis in some of these patients may make life easier and lessen pain. This situation should also be questioned and patients may need to be informed better about the prosthesis. In this group of patients, compliance with the restrictions on social activities was found to be significantly lower than those using long-term prosthesis. These data may indicate that the psychology of social restriction, not the pain itself, adversely affects the use of prosthesis, or that the pain itself has brought into the psychology of social restriction. In both cases, it is seen that psychological support should be provided to these patients with care as well as pain control.

Although there is a relationship between phantom or stump pain and daily prosthesis use and satisfaction, there may not be a direct correlation between the psychosocial acceptance of phantom and/or stump pain or satisfaction with the prosthesis. ${ }^{[2,25]}$ 
Sinha et al. ${ }^{[2]}$ reported that these pain did not significantly affect prosthesis satisfaction, psychosocial adjustment score, and activity restriction. Likewise, Desmond et al. ${ }^{[25]}$ stated that phantom pain did not affect psychosocial adjustment level. However, in our study, both phantom pain and stump pain were found to be significantly correlated with psychosocial conditions and limitations in activities and prosthesis satisfaction scores. These data indicate that patients should be better managed for pain management.

Cairns et al. ${ }^{[26]}$ reported that $39-57 \%$ of the participants were satisfied with the appearance of the prosthesis, wearability under clothing, waterproofness, ease of cleaning, and durability. In their study, they found that female patients were significantly less satisfied with respect to the aesthetic of the prosthesis than male patients and young people compared with older patients. Van de Weg and Van der Windt ${ }^{[23]}$ reported that $68.8 \%$ of patients were satisfied with the appearance of the prosthesis. Dillingham et al. ${ }^{[27]}$ reported that $43.1 \%$ of their patients were satisfied with the comfort of the prosthesis and $58.1 \%$ were satisfied with the appearance of the prosthesis. Sinha et al. ${ }^{[21]}$ found that the average satisfaction rate of the patients in the TAPES questionnaire was $81.7 \%$. In our study, although the average prosthesis satisfaction score was $81.7 \%$, the rate of patients who stated that they were satisfied with the aesthetics of the prosthesis, that is, "satisfied" or "very satisfied," was found to be $45.9 \%$. These low rates indicate that the prosthesis should be produced according to the wishes of the patients in terms of cosmetic or aesthetics aspects.

Sinha et al. ${ }^{[21]}$ reported that female patients had lower social cohesion than men and attributed this to the rare occurrence of amputated female patients in society and a slightly different view of amputated women. In our study, it was found that the scores of compliance with mean social limitations and compliance with daily activities were significantly higher in men than in women. These data may indicate that the amputation process is more easily accepted in men. In our study, it was noteworthy that mean stump and phantom pain scores were significantly higher in females than in males. These data indicate that women should be better pain controlled and/or that women are less tolerant of pain after amputation.

There were some limitations in our study. The fact that the number of patients with prosthesis followed in our clinic was not very high limited our access to the number required for analysis in each grouping and reduced the possibility of detailed examination of each criterion.

\section{CONCLUSION}

Our study is one of the rare studies conducted in Turkey regarding the satisfaction of prosthesis and some other compliance criteria in amputated patients. Our study data showed that especially stump and phantom pain were significantly related to both daily life of the prosthesis, compliance scores, and satisfaction scores for the pros- thesis, and these pains affect the psychological state of the amputees. These data indicate that the pain controls of amputated patients - especially female patients - need to be better managed and patients need more psychological support.

\section{Ethics Committee Approval}

This study approved by the Kartal Dr. Lütfi Kırdar Training and Research Hospital Clinical Research Ethics Committee (Date: 28.06.2018, Decision No: 2018/5I4/I32/8).

Peer-review

Internally peer-reviewed.

Conflict of Interest

None declared.

\section{REFERENCES}

1. Pernot HF, Winnubst GM, Cluitmans JJ, De Witte LP. Amputees in Limburg: Incidence, morbidity and mortality, prosthetic supply, care utilisation and functional level after one year. Prosthet Orthot Int 2000;24:90-6.

2. Gauthier-Gagnon C, Grisé MC, Potvin D. Enabling factors related to prosthetic use by people with transtibial and transfemoral amputation. Arch Phys Med Rehabil 1999;80:706-13.

3. Biddiss EA, Chau TT. Upper limb prosthesis use and abandonment: A survey of the last 25 years. Prosthet Orthot Int 2007;31:236-57.

4. Callaghan BG, Condie ME. A post-discharge quality of life outcome measure for lower limb amputees: Test-retest reliability and construct validity. Clin Rehabil 2003;17:858-64.

5. Harness N, Pinzur MS. Health related quality of life in patients with dysvascular transtibial amputation. Clin Orthop Relat Res 2001;383:204-7.

6. Callaghan BG, Sockalingam S, Treweek SP, Condie ME. A post-discharge functional outcome measure for lower limb amputees: Test-retest reliability with trans-tibial amputees. Prosthet Orthot Int 2002;26:113-9.

7. Bilodeau S, Hébert R, Desrosiers J. Questionnaire on the satisfaction of persons with lower-limb amputations towards their prosthesis: Development and validation. Can J Occup Ther 1999;66:23-32.

8. Gallagher P, MacLachlan M. The development and psychometric evaluation of the trinity arnputation and prosthesis experience scales (TAPES). Rehabil Psychol 2000:45;130-55.

9. Topuz S, Ülger Ö, Yakut Y, Sener G. Reliability and construct validity of the Turkish version of the Trinity amputation and prosthetic experience scales (TAPES) in lower limb amputees. Prosthet Orthot Int 2011;35:201-6.

10. Legro MW, Reiber GD, Smith DG, del Aguila M, Larsen J, Boone D. Prosthesis evaluation questionnaire for persons with lower limb amputations: Assessing prosthesis-related quality of life. Arch Phys Med Rehabil 1998;79:931-8.

11. Demet K, Martinet N, Guillemin F, Paysant J, André JM. Health related quality of life and related factors in 539 persons with amputation of upper and lower limb. Disabil Rehabil 2003;25:480-6.

12. Şimşek IE, Şener G, Yakut Y. Validity and reliability of Turkish version of Satisfaction with the prosthesis questionnaire in unilateral lower extremity. Fizyoter Rehabil 2010;21:81-6.

13. Demirdel UF, Bayramlar K. Investigation of the relationship of reintegration process to normal living after amputation with quality of life and functional level. Turk J Physiother Rehabil 2014;25:1-7.

14. Kark L, Simmons A. Patient satisfaction following lower-limb amputa- 
tion: The role of gait deviation. Prosthet Orthot Int 2011;35:225-33.

15. Matsen SL, Malchow D, Matsen FA. Correlations with patients' perspectives of the result of lower-extremity amputation. J Bone Joint Surg Am 2000;82:1089.

16. Zidarov D, Swaine B, Gauthier-Gagnon C. Quality of life of persons with lower-limb amputation during rehabilitation and at 3-month follow-up. Arch Phys Med Rehabil 2009;90:634-45.

17. O'Toole RV, Castillo RC, Pollak AN, MacKenzie EJ, Bosse MJ. Determinants of patient satisfaction after severe lower-extremity injuries. J Bone Joint Surg Am 2008;90:1206.

18. Ide M, Obayashi T, Toyonaga T. Association of pain with employment status and satisfaction among amputees in Japan. Arch Phys Med Rehabil 2002;83:1394-8.

19. Webster JB, Hakimi K, Williams RM, Turner AP, Norvell DC, Czerniecki JM. Prosthetic fitting, use, and satisfaction following lower-limb amputation. J Rehabil Res Dev 2012;49:1493-504.

20. Schoppen T, Boonstra A, Groothoff JW, de Vries J, Göeken LN, Eisma WH. Physical, mental, and social predictors of functional outcome in unilateral lower-limb amputees. Arch Phys Med Rehabil 2003;84:803-11.

21. Sinha R, van den Heuvel WJ, Arokiasamy P. Adjustments to ampu- tation and an artificial limb in lower limb amputees. Prosthet Orthot Int 2014;38:115-21.

22. Engin O, Dilek B, Gökmen HM, Sahin E, Kizil R, Karakasli A, et al. Functional restriction and satisfaction with prosthesis in lower limb amputee patients. DEÜ Tip Fakültesi Derg 2018;32:213-8.

23. van de Weg FB, van der Windt DA. A questionnaire survey of the effect of different interface types on patient satisfaction and perceived problems among trans-tibial amputees. Prosthet Orthot Int 2005;29:231-9.

24. Murray CD. The social meanings of prosthesis use. J Health Psychol 2005;10:425-41.

25. Desmond D, Gallagher P, Henderson-Slater D, Chatfield R. Pain and psychosocial adjustment to lower limb amputation amongst prosthesis users. Prosthet Orthot Int 2008;32:244-52.

26. Cairns N, Murray K, Corney J, McFadyen A. Satisfaction with cosmesis and priorities for cosmesis design reported by lower limb amputees in the United Kingdom: Instrument development and results. Prosthet Orthot Int 2014;38:467-73.

27. Dillingham TR, Pezzin LE, MacKenzie EJ, Burgess AR. Use and satisfaction with prosthetic devices among persons with trauma-related amputations: A long-term outcome study. Am J Phys Med Rehabil 2001;80:563-71.

\section{Periferik Anjiopati (Diabetik Ayak) Nedeniyle Ayakta Nekroz ve Yarası Nedeniyle Alt Ekstremite Amputasyonu Yapılan Hastaların Yaşam Kalitelerin Belirlenmesi}

Amaç: Amputasyonlar, günlük yaşam ve fonksiyonellik açılarından kişinin hayatında büyük değişikliklere yol açar. Amputasyondan dolayı meydana gelen vücut yapılarındaki ve vücut fonksiyonlarındaki sınırılık, aktivite seviyesini ve kişinin toplumsal katılımını etkiler. Bu çalışmada Trinity Amputasyon ve Deneyim Ölçeği (TAPES) anketinin Türkçe versiyonu kullanılarak amputasyondan sonra normal yaşama yeniden katıIım sürecinin yaşam kalitesi ve fonksiyonel düzey ile ilişkisinin incelenmesi amaçlandı.

Gereç ve Yöntem: Çalışmaya yaş ve cinsiyet farkına bakılmaksızın üçüncü basmak hastanemiz Ortopedi ve Travmatoloji kliniğine başvuran ve diyabetik ayak nedeniyle alt ekstremite amputasyonu yapılan toplam 48 hasta dahil edildi. Tüm hastalara ait Trinity Amputasyon ve Deneyim Ölçeği (TAPES) anketleri doldurularak kaydedildi.

Bulgular: Ankete dahil edilen 48 hastanın 36'sı (\%75.0) erkek, I2'si (\%25.0) kadındı. Toplam sekiz (\%।6.7) hastanın ampütasyonu diz üstü düzeyinden, 40 (\%83.3) hastanınki ise diz altından yapılmıştı. Protezi günlük 12 saatin üzerinde kullanan I4 (\%29.2) hasta varken, daha az süreyle kullananlar 34 (\%70.8) kişiydi. Hastaların ortalama yaşı 54.4 I 9.4 yıl (yaş aralığı: I I-86 yıl) idi. Protezden toplam memnuniyet skoru oranı \%63. $1 \pm 20.5$ (aralık: \%20-92) idi.

Sonuç: Çalışmamız ampüte hastalarda protezlere ve diğer bazı uyum kriterlerine karşı duyulan memnuniyet ile ilgili ülkemizde yapılmış nadir çalışmalardandır. Çalışmamız verileri özellikle güdük ve fantom ağrılarının hem protezin günlük kullanım süresiyle, hem uyum skorlarıyla hem de proteze karşı duyulan memnuniyet skorları ile anlamlı ilişkili olduğunu ve bu ağııların ampüte hastaların psikolojik durumunu etkilediğini göstermiştir.

Anahtar Sözcükler: Güdük ağrısı; fantom ağrısı; protez memnuniyet anketi; TAPES. 